\title{
ANALISIS KEMAMPUAN PEMECAHAN MASALAH MATEMATIKA MAHASISWA CALON GURU SEMESTER VI IKIP-PGRI PONTIANAK
}

\author{
Nurmaningsih \\ Program Studi Pendidikan Matematika, IKIP-PGRI Pontianak \\ nurmaazzahra99@mail.com
}

\begin{abstract}
Abstrak
Penelitian ini bertujuan untuk mendekripsikan kemampuan pemecahan masalah matematika mahasiswa calon guru semester VI IKIP-PGRI Pontianak. Secara khusus, penelitian ini bertujuan untuk mendeskripsikan kemampuan pemecahan masalah matematika mahasiswa calon guru semester VI IKIPPGRI Pontianak pada masing-masing aspek pemecahan masalah matematika. Dalam penelitian ini digunakan metode deskriptif dengan bentuk penelitiannya adalah studi kasus. Berdasarkan analisis data dapat disimpulkan bahwa: (1) Pada aspek memahami masalah, mahasiswa sudah menuliskan informasi yang ada pada soal namun masih terdapat kekurangan dan kesalahan dalam menentukan apa yang ditanyakan pada soal, (2) Pada aspek merencanakan penyelesaian, mahasiswa masih belum menuliskan rencana penyelesaian secara sistematis dan detail pada tiap langkah-langkahnya, (3) Pada aspek melaksanakan rencana penyelesaian, masih terdapat kesalahan dalam perhitungan sehingga menghasilkan jawaban yang kurang tepat, (4) Pada aspek memeriksa kembali hasil yang diperoleh, masih terdapat kesalahan dalam kesimpulan akibat dari kesalahan dalam memahami masalah dan juga kesalahan dalam perhitungan.
\end{abstract}

Kata kunci: pemecahan masalah, program linear

Abstract

This study aims to decrypt the problem solving skills of mathematics students prospective teacher semester VI IKIP-PGRI Pontianak. Specifically, this study aims to describe the mathematical problem solving skills of prospective teachers of semester VI of IKIP-PGRI Pontianak in each aspect of solving mathematical problems. In this study used descriptive method with the form of research is a case study. Based on the data analysis, it can be concluded that: (1) In the aspect of understanding the problem, the students have written information on the problem but there are still deficiencies and mistakes in determining what is asked on the question, (2) In the aspect of the plan of settlement, the student still has not written the plan (3) In the aspect of executing the settlement plan, there are still errors in the calculation so as to produce a less precise answer, (4) In the aspect of re-examining the results obtained, there is still a mistake in the conclusion of the result of Error in understanding the problem and also the error in the calculation.

Key word: problem solving, linear programming

\section{PENDAHULUAN}

Pembelajaran matematika tidak hanya sekedar menyampaikan berbagai informasi seperti aturan, definisi dan prosedur untuk dihafal oleh siswa, tetapi guru harus melibatkan siswa secara aktif dalam proses belajar mengajar. Keikutsertaan siswa secara aktif akan memperkuat pemahamannya terhadap konsep-konsep matematika. Hal ini sesuai dengan prinsip-prinsip konstruktivisme yakni pengetahuan dibangun sendiri oleh siswa.

Salah satu komponen proses pembelajaran matematika yang sangat penting adalah pemecahan masalah. Menurut Hudiono (2007: 9), bahwa pemecahan masalah dalam komponen proses lebih merupakan kemampuan siswa yang mengakumulasikan kemampuan-kemampuan proses lainnya, juga dapat merangkum dua kemampuan matematika lainnya yang menekankan pada aktivitas matematika dan memfasilitasi untuk mengembangkan kemampuan berfikir matematika.

Menurut Polya (1973: 110), solusi soal pemecahan masalah memuat 4 langkah fase penyelesaian, yaitu:

a. Memahami masalah

b. Merencanakan penyelesaian

c. Menyelesaikan masalah sesuai rencana

d. Melakukan pengecekan kembali .

Kemampuan pemecahan masalah perlu dikuasai siswa sebagai bekal bagi mereka dalam menghadapi masalah nyata dalam kehidupan sehari-hari maupun dalam dunia kerja. Hal inilah yang merupakan alasan mengapa kemampuan pemecahan masalah merupakan salah satu tujuan pembelajaran matematika dan menjadi salah satu standar kelulusan siswa (Depdiknas, 2006: 140).

Banyak masalah yang dapat diangkat dari berbagai situasi (konteks) yang dirasakan bermakna sehingga menjadi sumber belajar. Kenyataannya, pembelajaran 
matematika di sekolah bahkan perguruan tinggi belum menekankan pada pengembangan daya nalar (reasoning), logika dan proses berpikir. Pengajaran matematika umumnya didominasi oleh pengenalan rumus-rumus serta konsep-konsep secara verbal, tanpa ada perhatian yang cukup terhadap pemahaman siswa. Buku teks yang digunakan dalam pembelajaran masih sedikit membahas soal yang dapat mengembangkan kemampun pemecahan masalah matematis siswa. Menghadapi kondisi itu, pembelajaran matematika harus mengubah citra dari pembelajaran yang mekanistis menjadi humanistik yang menyenangkan.

Tentunya tujuan ini tidak hanya menjadi perhatian para guru dalam mengelola pembelajaran di kelas, tetapi juga para dosen yang mencetak para calon guru. Untuk membiasakan siswa menggunakan kemampuan pemecahan masalah, tentu saja para calon guru ini juga harus memiliki kemampuan pemecahan masalah terlebih dahulu. Oleh karena itu, jika kemudian mahasiswa dituntut mempunyai kemampuan pemecahan masalah yang baik, maka permasalahan yang kemudian muncul adalah bagaimanakah pembelajaran yang mampu untuk meningkatkan kemampuan pemecahan masalah mahasiswa calon guru. Dengan demikian, sebelum dikembangkan perangkat pembelajaran yang relevan, maka perlu dilakukan kajian awal tentang kemampuan pemecahan masalah mahasiswa calon guru di lingkungan IKIP-PGRI Pontianak.

\section{METODE}

Dalam penelitian ini digunakan metode deskriptif dengan bentuk penelitiannya adalah studi kasus. Penelitian deskritif tidak memberikan perlakuan-perlakuan, manipulasi atau pengubahan pada variabel-variabel atau merancang sesuatu yang diharapkan terjadi pada variabel, tetapi semua kegiatan, keadaan, kejadian, aspek, komponen atau variabel berjalan sebagaimana adanya.

Penelitian ini menggunakan studi kasus yang diuraikan secara deskriptif dari hasil jaringan pengumpulan data yang diperoleh dari tes kemampuan pemecahan masalah dan wawancara. Studi kasus atau case study adalah bentuk penelitian yang mendalam tentang suatu aspek lingkungan sosial termasuk manusia di dalamnya. Studi kasus dapat mengenai perkembangan sesuatu, dapat pula mengungkap sebab akibat, dan dapat pula penelitian yang ingin memberi gambaran tentang keadaan yang ada (Moxfild, dalam Nazir, 1998: 45).

Subjek dalam penelitian ini adalah salah satu kelas mahasiswa calon guru semester VI IKIP-PGRI Pontianak dan sudah mempelajari materi program linear baik di SMA maupun di semester $\mathrm{V}$.

Teknik pengumpul data dalam penelitian ini adalah teknik pengukuran. Pengukuran merupakan suatu usaha untuk mengetahui suatu keadaan berupa kecerdasan, kecakapan nyata (achievment) dalam bidang tertentu (Nawawi, 2005:125). Sementara alat pengumpul datanya adalah tes pemecahan masalah matematika pada materi Program Linear. Soal tes ini merupakan soal yang diadopsi dari penelitian terdahulu yaitu penelitian Marinda Ditya Putriari. Soal tes telah dinyatakan valid dan reliabel oleh peneliti terdahulu dan memiliki tingkat kesukaran sedang. Setelah data diperoleh dengan alat pengumpul data, maka data tersebut dianalisis secara deskriptif. Selanjutnya dari data tersebut akan dijelaskan bagaimana kemampuan pemecahan masalah matematika mahasiswa calon guru pada masing-masing aspek pemecahan masalah.

\section{HASIL DAN PEMBAHASAN}

Berikut ini disajian beberapa data dari aspek-aspek yang diteliti yaitu meliputi: (1) desrkripsi kemampuan pemecahan masalah matematika calon guru semester VI IKIP-PGRI Pontianak pada aspek memahami masalah, (2) desrkripsi kemampuan pemecahan masalah matematika calon guru semester VI IKIP-PGRI Pontianak pada aspek merencanakan pemecahan, (3) desrkripsi kemampuan pemecahan masalah matematika calon guru semester VI IKIP-PGRI Pontianak pada aspek menyelesaikan sesuai rencana, (4) desrkripsi kemampuan pemecahan masalah matematika calon guru semester VI IKIP-PGRI Pontianak pada aspek memeriksa kembali hasil yang diperoleh.

Pada aspek memahami masalah, mahasiswa dapat memahami masalah dengan cara melihat masalah tersebut secara lebih rinci meliputi apa yang diketahui dan ditanyakan, data-data apa saja yang dimiliki, dan apa hubungan dari hal-hal yang diketahui tersebut.

Sebanyak 46 mahasiswa yang diberi tes kemampuan pemecahan masalah, semuanya mencoba untuk menuliskan apa yang diketahui dan apa yang ditanyakan pada soal, namun tidak semuanya menjawab dengan lengkap dan benar.

Dari hasil analisis, diperoleh sebanyak 21 mahasiswa menuliskan informasi yang terdapat pada soal dengan lengkap dan tepat. Mulai dari yang diketahui sampai yang ditanyakan pada soal. Berikut ditampilkan salah satu jawaban mahasiswa yang menuliskan informasi dengan lengkap. 


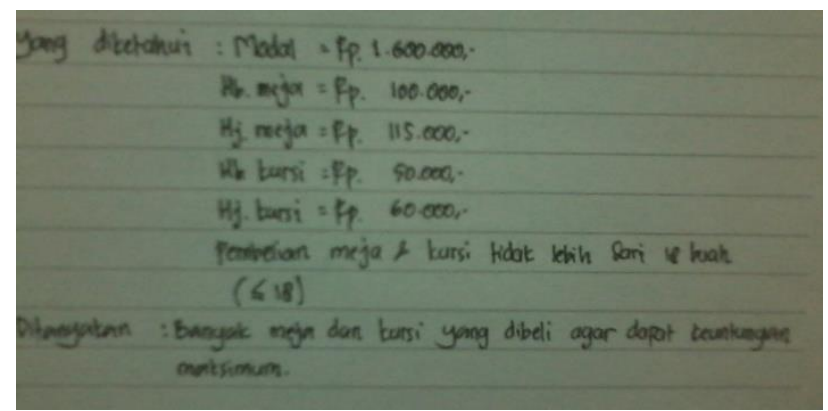

Gambar 1. Jawaban Mahasiswa yang Lengkap pada Aspek Memahami Masalah

Sebanyak 22 mahasiswa menuliskan beberapa informasi yang mereka ketahui pada soal, namun masih belum lengkap dan kurang tepat dalam menentukan apa yang ditanyakan. Berikut ditampilkan salah satu jawaban mahasiswa yang masih belum tepat dalam memahami masalah.

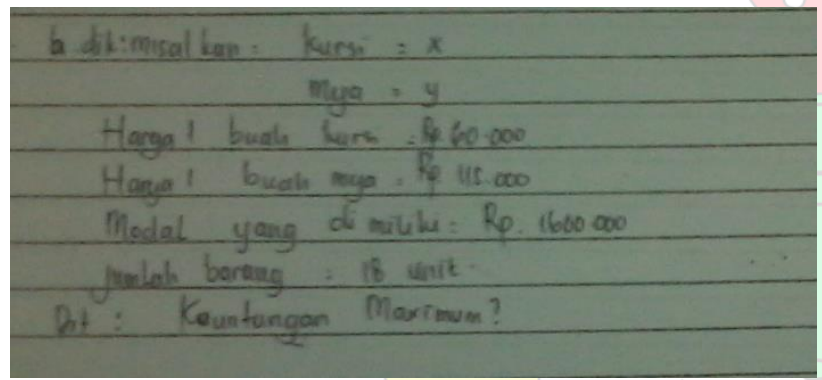

Gambar 2. Jawaban Mahasiswa yang Keliru pada Aspek Memahami

Selain jawaban-jawaban di atas, terdapat 3 mahasiswa yang menuliskan informasi baru yang tidak terdapat pada soal, akan tetapi mereka temukan dengan mengaitkan informasi-informasi yang sudah ada, yaitu mereka menuliskan keuntungan dengan mengaitkan antara harga jual dan harga beli yang sudah diketahui sebelumnya. Berikut jawaban mahasiswa tersebut.

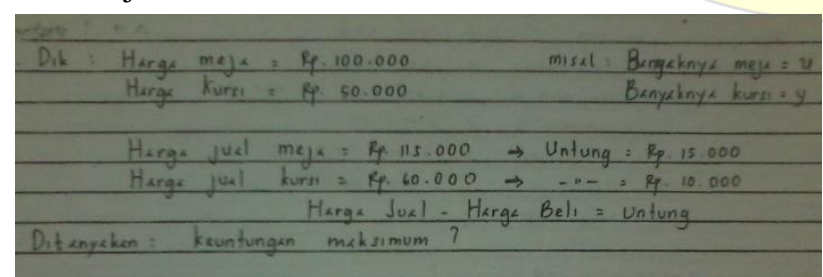

Gambar 3. Jawaban Mahasiswa yng Berbeda pada Aspek Memahami Masalah

Setelah mahasiswa dapat memahami masalah, prosedur berikutnya adalah merencanaan penyelesaian yakni menyusun langkah-langkah atau strategi penyelesaian untuk menjawab apa yang ditanyakan pada soal. Namun tidak semua mahasiswa menuliskan apa yang mereka rencanakan untuk menjawab permasalahan yang diberikan.
Sebanyak 24 mahasiswa tidak menuliskan rencana penyelesaian masalah, atau mencoba menjawab tetapi salah. Selebihnya yaitu sebanyak 22 mahasiswa menuliskan rencana penyelesaian masalah yang diberikan. Berikut ini ditampilkan salah satu bentuk jawaban mahasiswa dalam merencanakan penyelesaian masalah

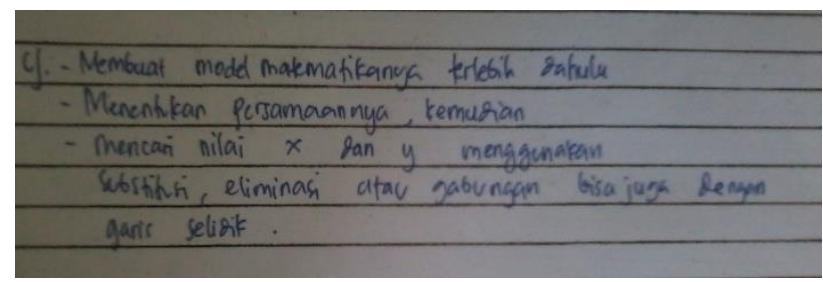

Gambar 4. Jawaban Mahasiswa pada Aspek

Penyelesaian Masalah

Pada aspek menyelesaikan sesuai rencana, harusnya mahasiswa dapat menyelesaikan masalah yang ditanyakan sesuai dengan langkah-langkah yang mereka rencanakan. Sebagian besar mahasiswa mencoba menyelesaikan permasalahan yang diberikan dengan menggunakan metode yang sering digunakan yaitu eliminasi, substitusi ataupun gabungan. Mereka menyelesaikan masalah sesuai dengan apa yang mereka tuliskan dalam perencanaan penyelesaian masalah. Salah satunya disajikan dalam gambar berikut ini

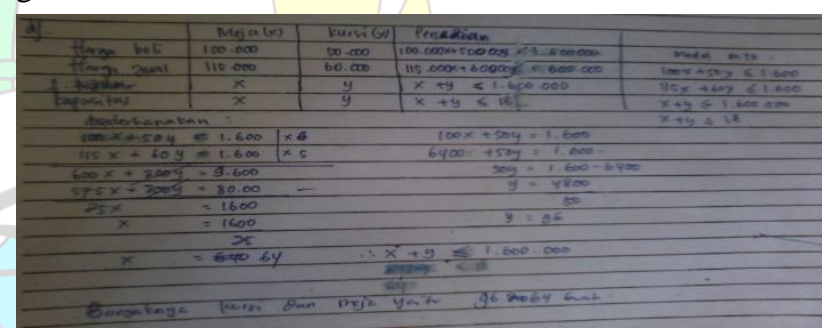

Gambar 5. Jawaban Mahasiswa pada Aspek Menyelesaikan Sesuai Rencana Tipe 1

Selain menggunakan metode eliminasi, substitusi ataupun gabungan, ternyata ada pula mahasiswa yang mencoba menyelesaikan dengan metode coba-coba, yakni dengan mencobakan jumlah kursi dan meja yang sesuai dengan syarat yang ada pada soal. Berikut disajikan jawaban mahasiswa tersebut.

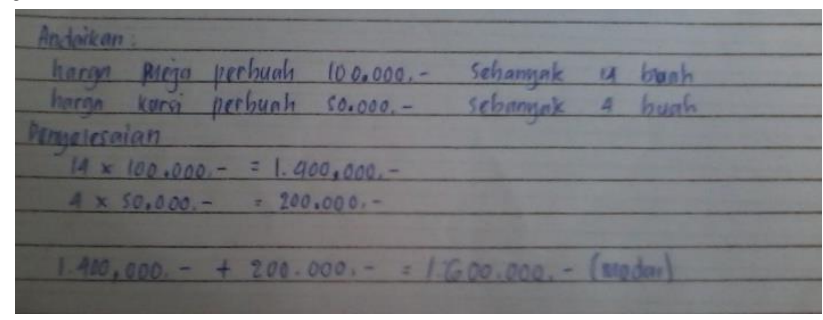

Gambar 6. Jawaban Mahasiswa pada Aspek Menyelesaiakn Sesuai Rencana Tipe 2 
Pada aspek memeriksa kembali hasil yang diperoleh, mahasiswa diminta untuk menyimpulkan jawaban yang mereka dapatkan setelah mereka melaksanakan rencana penyelesaian masalah. Artinya, mereka harus menafsirkan kembali model matematika ke dalam masalah nyata yang disajikan. Tentunya, hasil yang mereka peroleh bergantung dari proses mereka dalam menyelesaikan soal. Ketika mereka keliru dalam menuliskan apa yang ditanyakan, maka akan salah juga dalam menyimpulkan. Selain itu kesalahan juga dapat terjadi karena mereka salah dalam perhitungan.

Berikut ini disajikan salah satu bentuk kesimpulan yang dituliskan oleh mahasiswa.

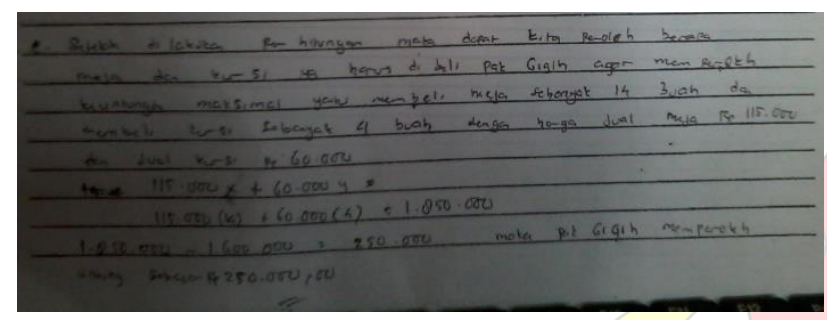

Gambar 7. Jawaban Mahasiswa pada Aspek Memeriksa Kembali

\section{KESIMPULAN}

Berdasarkan analisis data, maka secara umum dapat disimpulkan bahwa kemampuan pemecahan masalah matematika Mahasiswa Calon Guru semester VI Pada Materi Program Linear perlu ditingkatkan. Hal ini dapat dilakukan pada saat perkuliahan, dosen mengajar dengan memperhatikan aspek-aspek kemampuan pemecahan masalah matematika. Secara khusus, dapat disimpulkan sebagai berikut: (1) Pada aspek memahami masalah, mahasiswa sudah menuliskan informasi yang ada pada soal namun masih terdapat kekurangan dan kesalahan dalam menentukan apa yang ditanyakan pada soal, (2) Pada aspek merencanakan penyelesaian, mahasiswa masih belum menuliskan rencana penyelesaian secara sistematis dan detail pada tiap langkah-langkahnya, (3) Pada aspek melaksanakan rencana penyelesaian, masih terdapat kesalahan dalam perhitungan sehingga menghasilkan jawaban yang kurang tepat, (4) Pada aspek memeriksa kembali hasil yang diperoleh, masih terdapat kesalahan dalam kesimpulan akibat dari kesalahan dalam memahami masalah dan juga kesalahan dalam perhitungan.

\section{DAFTAR PUSTAKA}

Departemen Pendidikan Nasional. 2006. Kurikulum Tingkat satuan Pendidikan 2006. Jakarta.

Hudiono, B. 2007. Representasi dan Metakognisi dalam Sistem Persamaan Linear. Jurnal Ilmiah Nasional Pancaran Pendidikan,FKIP Jember,tahun XX (68): 1188-1196.

Nawawi, H. 1991. Metode penelitian Bidang Sosial. Jakarta: Gajah Mada University Press.

Nazir, M. 1998. Metode Penelitian. Jakarta: Ghalila Indonesia.

Polya, George. 1973. How to solve it, A New Aspect Matematical Method. New Jersey: Princeton University Press. dan Pembelajaran. Jogjakarta: Ar-Ruzz Media. 